\title{
Evaluation of the AirLand Battle Management Advanced Technology Demonstration Prototype Version 1.2: Knowledge Base Assessment of the Location Analysis Applications
}

\author{
Paul E. McKeown \\ CAE-Link Corporation
}

Field Unit at Fort Leavenworth, Kansas Stanley M. Halpin, Chief

Manpower and Personnel Research Division

Zita M. Simutis, Director

U.S. Army Research Institute for the Behavioral and Social Sciences

5001 Eisenhower Avenue, Alexandria, Virginia 22333-5600

Office, Deputy Chief of Staff for Personnel

Department of the Army

March 1994 